\title{
Use of pan-hemoplasma PCR for screening horses highly exposed to tick bites from southern Brazil
}

\section{Uso de PCR universal de hemoplasma para avaliação de cavalos altamente expostos a picadas de carrapato no Sul do Brasil}

\author{
Thállitha Samih Wischral Jayme Vieira ${ }^{1}$; Odilon Vidotto ${ }^{2 *}$ \\ Ana Márcia Sá Guimarães ${ }^{3}$; Andrea Pires dos Santos ${ }^{3}$; \\ Naíla Cannes do Nascimento ${ }^{3}$; Mariane Angélica Pommerening Finger; \\ Ivan Roque Barros-Filho ${ }^{5}$; Peterson Triches Dornbusch ${ }^{5}$; \\ Alexander Welker Biondo ${ }^{5}$; Rafael Felipe da Costa Vieira ${ }^{5}$; Joanne Belle Messick ${ }^{6}$
}

\begin{abstract}
Mycoplasma sp. are hemotropic bacteria of red blood cells and the causative agent of hemoplasmosis. Diagnosis of infection is reached by polymerase chain reaction (PCR) and real-time PCR (qPCR) of the 16S RNA gene of this bacteria. The aim of this study was to screen horses for Mycoplasma sp. infection using a pan-hemoplasma SYBR green qPCR assay. A total of 198 blood samples from horses were collected, DNA extracted and pan-hemoplasma qPCR performed. All samples were negative by qPCR. To verify the presence of amplifiable DNA, PCR for glyceraldehyde-3-phosphate dehydrogenase gene was performed on all samples. This study was part of an active surveillance program, which is critical for monitoring animal health status, particularly in horses.
\end{abstract}

Key words: Hemotropic mycoplasma, haemobartonellosis, carthorses, real-time PCR

\section{Resumo}

Mycoplasma sp. são bactérias hemotrópicas dos eritrócitos e é o agente causador da hemoplasmose. O diagnóstico da infecção é realizado pela reação em cadeia da polimerase (PCR) e PCR em tempo real (qPCR) baseada no gene 16S RNA desta bactéria. O objetivo deste estudo foi avaliar cavalos para a infecção por Mycoplasma sp. utilizando um protocolo de SYBR green qPCR universal para hemoplasmas. Um total de 198 amostras de sangue de cavalos foram coletadas, o DNA foi extraído e a qPCR universal para hemoplasmas realizado. Todas as amostras foram negativas pela qPCR. Para verificar a presença de DNA amplificável, PCR para o gene gliceraldeído-3-fosfato desidrogenase foi realizada em todas as amostras. Este estudo foi parte de um programa de vigilância ativa, o qual é

\footnotetext{
${ }^{1}$ Discente Programa de Pós-Graduação em Ciência Animal, Universidade Estadual de Londrina, UEL, Londrina, PR, Brasil. E-mail: vieiratsjw@gmail.com

2 Prof. Dr., Dept ${ }^{\mathrm{o}}$ de Medicina Veterinária Preventiva, UEL, Londrina, PR, Brasil. E-mail: vidotto@uel.br

${ }^{3}$ Pesquisadores, Purdue University, West Lafayette, Indiana, EUA. E-mail: aguimara@purdue.edu; santos1@purdue.edu; ncannes@purdue.edu,

${ }^{4}$ Discente Programa de Pós-Graduação em Ciências Veterinárias, Universidade Federal do Paraná, UFPR, Curitiba, PR, Brasil. E-mail: mari.finger.ufpr@gmail.com

${ }^{5}$ Profs., Dept ${ }^{\mathrm{o}}$ de Medicina Veterinária, Universidade Federal do Paraná, UFPR, Curitiba, PR, Brasil. E-mail: ivanbarf@ufpr.br, petriches@gmail.com, abiondo@illinois.edu,rvieira@ufpr.br

${ }^{6}$ Prof., Purdue University, West Lafayette, Indiana, EUA. E-mail: jmessic@purdue.edu

* Author for correspondence
} 
crucial para o monitoramento do estado de saúde animal, particularmente em cavalos.

Palavras-chave: Micoplasma hemotrópico, hemobartonelose, cavalos de carroceiros, PCR em tempo real

Hemotropic mycoplasmas (hemoplasmas), the causative agent of hemoplasmosis, are small pleomorphic bacteria that infects a wide range of mammalian species worldwide (MESSICK, 2004). Hemoplasmas were initially classified in the order Rickettsiales. However, analysis of the $16 \mathrm{~S}$ ribosomal (rRNA) gene showed that Haemobartonella and Eperythrozoon were more related to the pneumoniae group of mycoplasmas, leading to the reclassification within the genus Mycoplasma (RIKIHISA et al., 1997; NEIMARK et al., 2001).

The first report documenting Haemobartonellalike infection in horses occurred in Nigeria, and it was based on the observation of the bacteria attached to the red blood cells by light microscopic examination of blood smears stained with Giemsa (GRÉTILLAT, 1978). However, molecular detection of hemoplasma infection was only recently reported in horses from Northern Germany, and the bacteria in the two infected horses were closely related to 'Candidatus Mycoplasma haemobos' and Mycoplasma haemofelis (DIECKMANN et al., 2010). In Brazil, there are no studies regarding the occurrence of hemoplasmas in this animal species.

The economic relevance of horses in Brazil is due to the various activities performed by this animal species, such as farm work, equestrian sports, meat, national and international trade, semen trade, hippotherapy, and in some regions are also used to pull carts and move throughout the cities with their owners to collect recycling materials.

Due to the social-economic importance and the lack of information regarding the epidemiology of this pathogen in horses, the aim of this study was to screen this animal species for Mycoplasma sp. infection using conventional and real-time polymerase chain reaction (qPCR) assays based on
16S rDNA gene of this bacteria.

The study was performed in five cities located in two regions (northern and south-central) of Paraná State, southern Brazil. Anticoagulated (EDTA) blood samples were taken from 198 apparently healthy horses of different breeds, ages, and gender, and stored at $-20^{\circ} \mathrm{C}$ until molecular procedures were run. In the northern region, 32 horses from a rural settlement (RS), and 24 cart horses from Londrina city were sampled. In the south-central region, 142 horses from urban areas were sampled as follows: 48 from Colombo, 76 from Pinhais and 18 from Curitiba city. During the sampling, the owners responded to an epidemiological questionnaire addressing the horse breed, age, gender and presence of ticks.

DNA was extracted from $200 \mu \mathrm{L}$ of whole blood samples using the Illustra ${ }^{\mathrm{TM}}$ blood genomicPrep Mini Spin Kit (GE Healthcare, Chalfont, St. Giles, UK), according to the manufacturer's instructions. Negative control purifications using ultra-pure water were performed in parallel to monitor crosscontamination with each batch of 30 samples. To ensure successful DNA extraction and absence of PCR inhibitors, a PCR for the housekeeping gene glyceraldehyde-3-phosphate dehydrogenase (GAPDH) was performed, as previously described (BIRKENHEUER et al., 2003). All samples were screened by pan-hemoplasma qPCR, as previously described (WILLI et al., 2009). Samples were also screened by conventional PCR using a bacterial universal primer set (MESSICK et al., 1998) and oligonucleotides targeting the $16 \mathrm{~S}$ rDNA regions specific for hemoplasmas (DIECKMANN et al., 2010). Reactions were performed using known positive samples for $M$. haemofelis, 'Candidatus Mycoplasma haemominutum', 'Candidatus Mycoplasma turicensis', M. wenyonii, M. ovis, and 
M. suis, and water as negative control.

Although housekeeping gene DNA and positive controls were successfully amplified, all 198 horse samples tested negative by qPCR and conventional PCR assays. The horses appear to have been heavily exposed to ticks based on finding $97.5 \%$ and $50 \%$ seropositivity for equine piroplasmosis agents (VIEIRA et al., 2013a) and Ehrlichia spp. (VIEIRA et al., 2013b), respectively. This finding was somewhat surprising since, ticks (Rhipicephalus sanguineus in the dog) have been implicated in the transmission of these organisms (SENEVIRATNA et al., 1973). To the author's knowledge, molecular detection of hemoplasma infection in horses were only previously described in Germany. The animals in this study were ill, suffering from fever, apathy, lymphadenitis, circulatory disorders, and pale mucosa (DIECKMANN et al., 2010). In this study, horse samples were first screened by the SYBR green qPCR assay, with positive samples submitted to conventional PCR assays targeting the $16 \mathrm{~S}$ rRNA gene. Our study followed the same methodology, however all horse samples tested negative. In contrast, the animal in our study were clinically healthy, which may explain the different results.

Active surveillance programs are critical for monitoring animal health status, particularly in carthorses, because they may act as sentinels and urban disseminators for infectious agents. Given the use of pan-hemoplasma primers in the qPCR and a universal primers in the conventional assays, it is unlikely that even a novel hemoplasma infecting the horse would have been missed. While healthy horses are unlikely to have a hemoplasma infection, the significance of an infection in a sick horse warrants further investigation.

\section{References}

BIRKENHEUER, A. J.; LEVY, M. G.; BREITSCHWERDT, E. B. Development and evaluation of a seminested PCR for detection and differentiation of Babesia gibsoni (Asian genotype) and B. canis DNA in canine blood samples. Journal of Clinical Microbiology,
Washington, v. 41, n. 9, p. 4172-4177, 2003.

DIECKMANN, S. M.; WINKLER, M.; GROEBEL, K.; DIECKMANN, M,P.; HOFMANN-LEHMANN, R.; HOELZLE, K.; WITTENBRINK, M. M.; HOELZLE, L. E. Haemotrophic Mycoplasma infection in horses. Veterinary Microbiology, Barcelona, v. 145, n. 3-4, p. 351-353, 2010.

GRÉTILLAT, S. L'he'mobartonellose equine au Niger. Bull Acad Vet France, v. 51, p. 351-358, 1978.

MESSICK, J. B. Hemotrophic mycoplasmas (hemoplasmas): a review and new insights into pathogenic potencial. Veterinary Clinical Pathology, Madison, v. 33, n. 1, p. 2-13, 2004.

MESSICK, J. B.; BERENT, L. M.; COOPER, S. K. Development and evaluation of a PCR-based assay for detection of Haemobartonella felis in cats and differentiation of $\mathrm{H}$. felis from related bacteria by restriction fragment length polymorphism analysis. Journal of Clinical Microbiology, Washington, v. 36, n. 2, p. 462-466, 1998.

NEIMARK, H.; JOHANSSON, K. E.; RIKIHISA, Y.; TRULLY, J. G. Proposal to transfer some members of the genera Haemobartonella and Eperythrozoon to the genus Mycoplasma with descriptions of 'Candidatus Mycoplasma haemofelis', 'Candidatus Mycoplasma haemomuris', 'Candidatus Mycoplasma haemosuis' and 'Candidatus Mycoplasma wenyonii'. International Journal of Systematic and Evolutionary Microbiology, London, v. 51, n. 3, p. 891-899, 2001.

RIKIHISA, Y.; KAWAHARA, M.; WEN, B.; KOCIBA, G.; FUERST, P.; KAWAMORI, F.; SUTO, C.; SHIBATA, S.; FUTOHASHI, M. Western immunoblot analysis of Haemobartonella muris and comparison of $16 \mathrm{~S}$ rRNA gene sequences of $\mathrm{H}$. muris, $\mathrm{H}$. felis, and Eperythrozoon suis. Journal of Clinical Microbiology, Washington, v. 35, n. 4, p. 823-829, 1997.

SENEVIRATNA, P.; WEERASINGHE, N.; ARYIADASA, S. Transmission of Haemobartonella canis by the dog tick Rhipicephalus sanguineus. Research in Veterinary Science, Oxford, v. 14, n. 1, p. 112-114, 1973.

VIEIRA, R. F. C.; VIEIRA, T. S. W. J.; NASCIMENTO, D. A. G.; MARTINS, T. F.; KRAWCZAK, F. S.; LABRUNA, M. B.; CHANDRASHEKAR, R.; MARCONDES, M.; BIONDO, A. W.; VIDOTTO, O. Serological survey of Ehrlichia species in dogs, horses and humans: zoonotic scenery in a rural settlement from southern Brazil. Revista do Instituto de Medicina Tropical de São Paulo, São Paulo, v. 55, n. 5, p. 335-340, $2013 \mathrm{~b}$. 
VIEIRA, T. S. W. J.; VIEIRA, R. F. C.; FINGER, M. A. P.; NASCIMENTO, D. A. G.; SICUPIRA, P. M. L.; DUTRA, L. H.; DECONTO, I.; BARROS-FILHO, I. R.; DORNBUSCH, P. T.; BIONDO, A. W.; VIDOTTO, O. Seroepidemiological survey of Theileria equi and Babesia caballi in horses from a rural and from urban areas of Paraná State, southern Brazil. Ticks and Tick Borne Diseases, Lippersdorf, v. 4, n. 6, p. 537-541, $2013 \mathrm{a}$.
WILLI, B.; MELI, M. L.; LÜTHY, R.; HONEGGER, H.; WENGI, N.; HOELZLE, L. E.; REUSCH, C. E.; LUTZ, H.; HOFMANN-LEHMANN, R. Development and application of a universal hemoplasma screening assay based on the SYBR Green PCR principle. Journal of Clinical Microbiology, Washington, v. 47, n. 12, p. 40494054, 2009. 